\title{
㣀 料
}

\section{鋼溶接時の低温割れと水素の影響*}

稲 垣道夫** 中村治 方**

\section{Low-Temperature Weld Cracks in Steels and Effect of Hydrogen on their Cracks*}

By Michio Inagaki** and Harumasa Nakamura**

\section{1. 緒言}

炭素鋼, 高張力鋼, 合金鋼などの溶接継手には, 大別 して溶接施工時に生ずる低温割れおよび実際使用中に生 ずる水素劣化による割れの 2 種類の水素に起因する破壊 現象がしばしば経験されている，前者の溶接低温割れに は, 初層溶接時のビード下割れ, ルート割れ, 多首溶接 時のミクロおよびマクロ割れなどがあり, 後者の使用時 の水素劣化割れには, 硫化物腐食割れ, 高温高压におけ る水素アタックなどをあげることができる.

てれらの破壊現象は, その発生の様相, 時期, 温度な どがそれぞれ異なるけれどあ, いずれすその本質は鋼の 水素劣化現象である. 今回はこれらの水素に起因する各 種の破壊現象のうち, 溶接低温割れについて述べるとと とする.

\section{2. 低温割れの諸因子}

低温割れの代表的なあのの 1 つであるビード下割れに ついては数多くの研究が行なわれているが, それらの結 果によるとビード下割れに影響する因子として, 硬化組 織と水素をあげるととには異論がない，また後に述べる 小林, 滝本の研究結果 ${ }^{1)}$ や Weiss らの実験結果 2 などか ら, 鋼の強さのレベルにより程度の差はあるにしても， 拘束力もビード下割れの 1 因子と考えるのが妥当であ る.

低水素系溶接棒を用いても発生するルート割れについ ては, Fig. 1 に示した $8 \mathrm{C}$ 鋼 (T-1 鋼) の各種寸法の $\mathrm{y}$ 開先拘束割れ試験結果3)からわかるように，溶接部の 冷却過程がはやくなるにしたがって割れが顕著になると 同時に, 試験片側面スリットを潹くきり込んで, 試験片 の拘束度を軽減すると割れが発生しなくなる．さらに

* 原稿受付 昭和 42 年 2 月 20 日

** 正員 金属材料技術研究所 National Research Institute for Metals
Fig. 2 亿示した水素量以外の諸性質が ほとんど同じ試 作溶接棒によるU 開先拘束割れ試験結果加ら, 冷却過 程が同じでも水素試験による拡散性水素量が多くなると ルート割れが顕著になるととがわかる（冷却速度 $3^{\circ} \mathrm{C} /$ sec の割れ率参照). 以上のととからルート割れについ

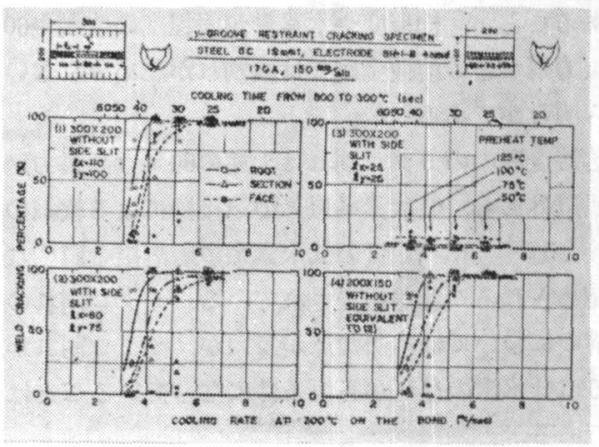

Fig. $1 \mathrm{~T}-1$ 鋼の y 開先拘束割れ試片寸法の影響

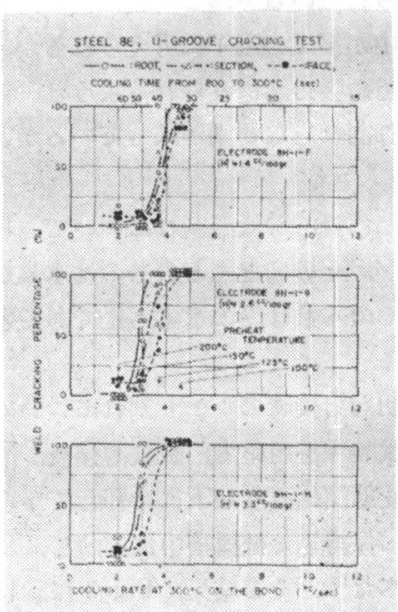

Fig. 2 HT 80 用棒のU開先拘束割れ試験結果に 及ぼす水素量の影響 
ても硬化組織，水素および拘束力がその因子と考えられ る.

止端割れについては系統的な実験結果が少ないが，小 林 $\left.{ }^{4}\right)$ にる自硬性 Ni-Cr-Mo 鋼についての実験結果で は, 止端割れはマルテンサイト変態進行中に発生し, そ の因子として硬化組織が考えられ，水素はこれには関与 しないと述べられている．著者らの行なった低合金高張 力鋼によるスリット形割れ試験では，とくに割れ感受性 の大きい鋼種においてルート割れと同時に止端割れあ発 生し，予熱を併用するととによりこれらの割れ発生を防 止できるととを経験している，乙の結果から低合金高張 力鋼においては止端割れはルート割れとどうような機構 で発生し，ただ応力集中により発生する個所だけが異な るあのと理解している.

$\mathrm{T}-1$ 鋼による球形タンクの建造の初期に経験された多 層溶接金属の横割れ(5)6)は，ミミクロ割れがつらなったす のであり, 拘束力および水素がこの割れ発生に影響をお よぼすことが示されているが，溶接金属の強度レベルが 高い，換言すれば硬化組織であるととす割れ発生の一因 であることが，拘束度や水素量が同程度の軟鋼や 60 キ口 高張力鋼などの溶接金属では横割れが認められないとと から明らかである.

溶接金属中のミクロ割れは上述の80キ口高張力鋼溶接 金属以外にも，低水素系以外の溶接棒による軟鋼の 1 層 溶接金属 ${ }^{7}{ }^{7}$-12) や軟鋼 の低水素系多層溶接金属 ${ }^{13}$ などに あ認められることが報告されている．ミラロ割れの発生 機構のについては不明な点が多いが，ミクロ割れが発生 するには水素の存在が必要条件になっていることは明ら かである.

溶接後, 母材原質部に割れが発生することが自硬性合 金鋼で認められている ${ }^{14)}$. この種の割れ発生には溶接残 留応力の集中が第 1 の因子に考えられるが，その因子以 外に最近の超高張力鋼にみられるような，鋼中の微量水 素による遅れ割れ的な要素が入っているかどうか明らか でない.

以上述べた代表的な低温割れについて，1，2の不明な あの屯あるが，そのほとんどのあのは水素が関与した割 れであり，その本質は鋼の水素劣化であるとみることが できる.

高張力鋼初層溶接時のルート割れについて，スリット 形拘束割れ試験片を用いて, 試験溶接後, 溶接部がマル テンサイト変態開始温度以下に冷却してから, 試験片を 種々の温度に保持した低温槽中に浸漬し，ルート割れ発 生時期を調べた ${ }^{15)}$. その結果，Fig. 3 亿示したような直 線関係がえられ，乙の直線の勾配から求められる活性化 エネルギーの值 $(10,540 \mathrm{cal} / \mathrm{gr}$. atom) は，との温度範

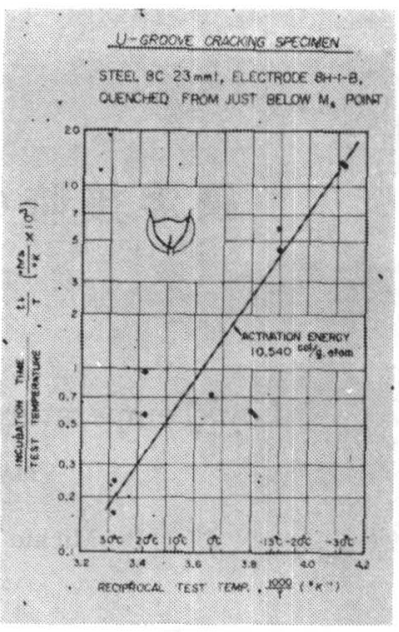

Fig. 3 U開先拘束割れ試験片に扔ける $t_{i} / T$ (潜伏期 間/絶対強度）と絶対温度の逆数との関係

囲における $\alpha-\mathrm{Fe}$ 中の水素の拡散の活性化エネルギー值 とほぼ等しい，また Flanigan, Kaae によるビード下割 れの活性化エネルギーの測定結果 ${ }^{16)}$ によると, その值が 約 9,100 cal/mol であり, やはり $\alpha-\mathrm{Fe}$ 中の水素の拡散 の活性化エネルギー値にほぼ一致する．乙れらの結果か ら，少なくともルート割れ，およびビード下割れについ ては, 割れが発生するには水素の拡散が必要であるこ之 が明らかであり，また次節で述べるようにかなりの実験 結果においてての水素の拡散, 集積にある時間（割れ発 生の潜伏期間) が必要であることが示されている。した がって鋼の水素劣化である低温割れむ，そのあらわれ方 がいわゆる遅れ割れ (Delayed Cracking) または遅れ 破壊（Delayed Failure）の形態をとるととに大きな特 長があり, ある組織, 拘束力および系全体の水素量の状 態で最初に割れを生じなくても, 時間の経過とともに割 れを発生するにいたる.

\section{3，束拘力の影響}

今迄の研究結果によれば, ビード下割れ、ルート割れ および多首溶接時のマクロ割れについては，割机におよ ぼす拘束力の影響は実証されているが，軟鋼溶接金属中 に生ずるミクロ割れについてはその影響を具体的に示し た実験結果はない．とこでは前者の 3 種の割れについて 述べる.

\section{1 ピード下割れ}

Weiss ら²)によと, アーマー鋼の 3 パスビード置き 試験, CTS 試験招よび十字形割れ試験を低水素系溶接 棒を用いて行なった結果， 500 および $300^{\circ} \mathrm{C}$ までの泠却 過程は同じであっても，十字形割れ試験ではビード下割 れを生じたが，他の 2 種の割れ試験では割れが認められ 
なかった．との結果から，Weissらはアーマー鋼のビー ド下割れには外的拘束が大きな影響をもつと結論してい る.

ビード下割れについて拘束力の影響をはじめて定量的 に明らかにしたのは，小林および滝本の実験1である. ての研究は，わが国において低温割れにおよぼす拘束力 の影響を定量的に扱かった最初のあのとして，またビー ド下割れが羊れ割れであるととを明らかにしたあのとし て注目すべきものである.

これによると， $0^{\circ} \mathrm{C}$ に予冷した 50 キ口高張力鋼板をセ ルローズ系溶接棒で溶接して 1 時間後に 2 時間の連続引 張負荷を与えた場合, 外的引張応力值が $25 \mathrm{~kg} / \mathrm{mm}^{2}$ 以 上になるとビード下割れが発生するてとが示されてい る. また $30 \mathrm{~kg} / \mathrm{mm}^{2}$ の引張応力值の下では, 1 時間ま での連続負荷ではビード下割れの発生が認められないて とや低水素系溶接棒を使用した場合には $50 \mathrm{~kg} / \mathrm{mm}^{2} \times 2$ hrs の引張負荷ではやはりビード下割れが認められない ことも示されている.

以上の結果から，ビード下割れは水素による遅れ割れ であることが明らかであるが，ビード下割れを発生する 水素量および拘束力の限界值は, 鋼の強さのレベルに応 じて変わるので, 見掛け上, ビード下割れにおよぼす拘 束力の影響がないようにみなされる場合ああるが，実際 には組織, 水素および拘束力か影響してビード下割れを 生ずるあのと考えられる。

\section{2 ルート割れ}

ルート割れは溶接部の冷却過程が同じ場合には，すみ 肉溶接より突合せ溶接において顕著であることが高張力 鋼について求められている(17)ので, ここでは突合せ溶接 の場合について述べる.

突合せ溶接継手の拘束係数は渡辺, 佐藤の試作した拘 束度計 ${ }^{18}{ }^{19}$ によって測定でき, また拘束係数之拘束力ゃ 拘束応力との関係式む求められている.

実験室的に, ルート割れにおよぼす拘束力の定量的な 影響を調べるために，TRC 試験 $(\text { 金材研 })^{20) 21}$ および RRC 試験（阪大 ${ }^{22}$ )か開発された. TRC 武験 (Tensile Restraint Cracking Test) は溶接終了後, 定荷重長時 間引張試験を行なう方式であり, 遅れ割れ試験用に用い られる. RRC 試験 (Rigid Restraint Weld Cracking Test）は溶接後, 溶接線を中心とする任意の標点距離を 冷却中, 常に一定に保持する試験方法で, 冷却途上飞起 こる割れおよび遅れ割れ試験用に用いられる.

高張力鋼の $\mathrm{TRC}$ 試験において, 初層溶接終了後, 溶 接線直角方向に定荷重負荷を与えると, Photo. 1 亿示 したようなルート割れが，Fig.4 亿示したように，ある

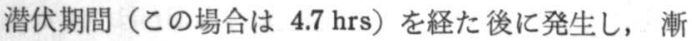

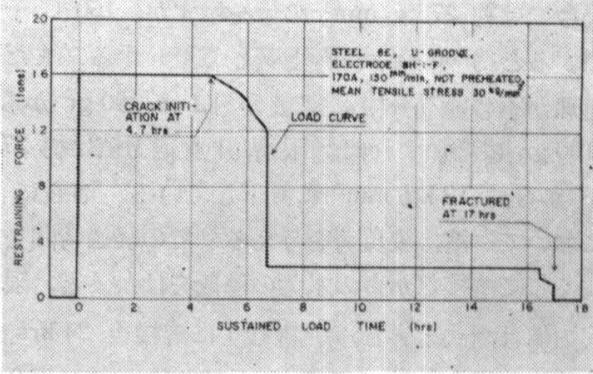

Fig. 4 TRC 試験における定荷重負荷による荷重 一時間曲線の例

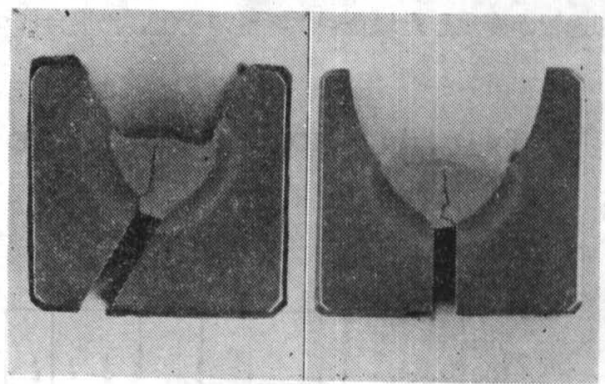

Photo. 1 (a)

TRC 試験における $\mathrm{y}$

開先ルート割れの例

Photo. 1 (b)

TRC 試験におけるU 開先ルート割れの例

次割れが進展してついには破断する. 引張応力值を種々 変えて, 割れ発生の有無を調べると, それ以下の引張応 力值ではルート割れが発生しないという，いわゆる限界 引張応力值が存在するととがわかる，いま，代表的な 80 キ口高張力鋼 (以下, HT 80 と記す) である， T-1 鋼 初層溶接継手につき, 引張応力值を変えてルート割れの 発生時期および破断時間を求めて図示すると Fig. 5 に 示したようになる. この図からルート割れ発生の限界引 張応力値は溶接部の泠却過程 (予熱温度) 之水素量によ

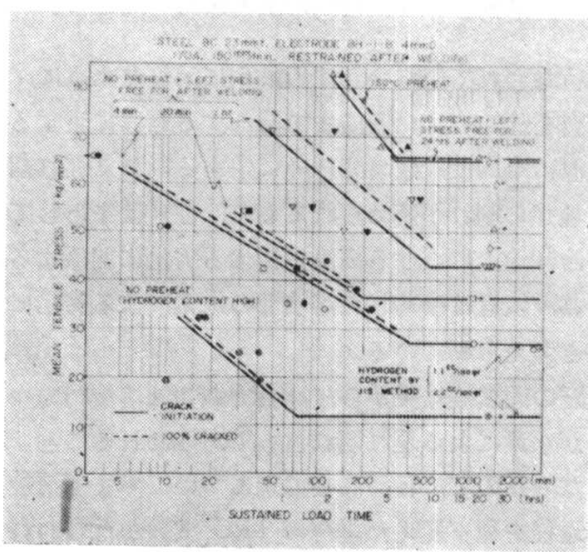

Fig. $5 \mathrm{~T}-1$ 鋼溶接部の U開先 TRC 試験結果 
って変化するととがわかる．すなわち，予熱を行なわな い場合には約 $27 \mathrm{~kg} / \mathrm{mm}^{2}$ の值を示すが, $150^{\circ} \mathrm{C}$ 予熱を 併用すると約 $66 \mathrm{~kg} / \mathrm{mm}^{2}$ と著しく上昇する. また再乾 燥処理が不じゆう分で水素量が $1.1 \mathrm{cc} / 100 \mathrm{gr}$ から 2.2 $\mathrm{cc} / 100 \mathrm{gr}$ に増加すれば, 限界引張応力值は約 $27 \mathrm{~kg} /$ $\mathrm{mm}^{2}$ 加約 $12 \mathrm{~kg} / \mathrm{mm}^{2}$ 亿低下している. さらに Fig. 5 亿おいて, 溶接後負荷を与えるまでの経過時間を故意 に長くして溶接部加らの水素の逃散をはかると, 限界引 張応力値は漸次上昇し, 予熱せずに溶接後 $24 \mathrm{hrs}$ 無負 荷放置した場合には，その值が $150^{\circ} \mathrm{C}$ 予熱の場合に匹 敵する値を示すととは興味深い。

いっぽう，RRC 試験においては試験方法の関係上, 冷却過程が変化した場合や水素量の変化した場合につい

\section{KEY}

FRACTURE NOCRACKING PLATE

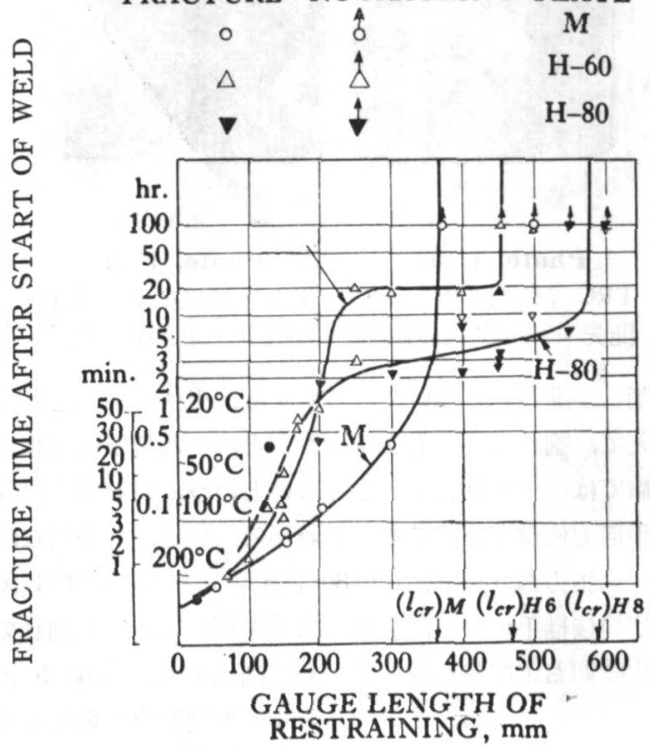

Fig. 6 軟鋼, HT 60 および HT 80 溶接部の RRC 試験における拘束距離之破率時間との関係

ては行なわれていないが, Fig. 6 に示したように，軟鋼 の場合を除いては, 室温まで泠却する過程に生ずる割れ と室温に冷却後, 数時間以降に生ずる割れ（遅れ割れ） の 2 種類の割れが認められており, 前者は主として溶接 部が冷却途上にうける高温歪による劣化に関係すると考 えられ, 後者は冷却した溶接部の水素による劣化に起因 すると考えられている.

上記の両試験結果から, 高張力鋼初層溶接時のルート 割れが水素による遅れ割れとしてあらわれることが明ら かとなったので，各種高張力鋼について，まず溶接部の 冷却過程を種々変えた場合の TRC 試験が行なわれた. その結果の数例を Fig. 7 に示したが, 7C (HT 70) お

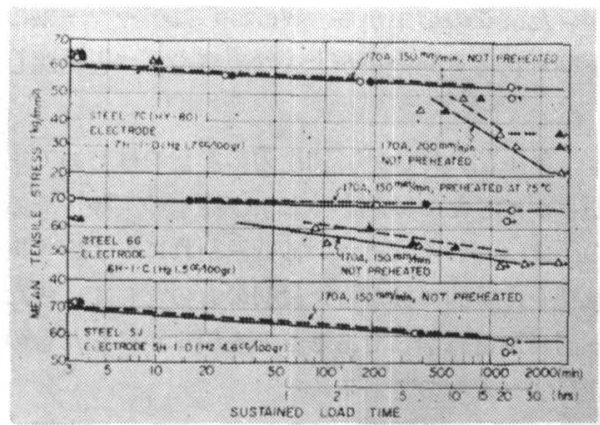

Fig. 7 各鋼種の $\mathrm{y}$ 開先 TRC 試験結果

よび 6G（HT 60）鋼においても HT 80 の場合とどう よう, 溶接部の冷却過程を緩慢にすれば, 限界応力值の 上昇が認められる。乙れらの各種 TRC 試験結果を限界 応力值と潜伏期間についてまとめたのが Fig. 8 であ る. 図中，斜線を施して示したのは，同一供試材につき スリット形拘束割れ試験を行なった場合にールート割れ

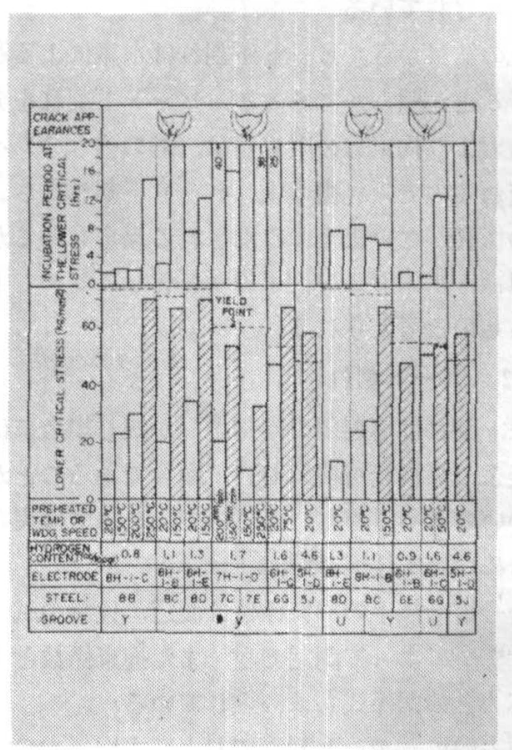

Fig. 8 各種鋼材の TRC 試験による限界応力值に 及ぼす溶接諸条件の影響

の発生か防止できる予熱温度または溶接速度である。一 般に TRC 試験において, 限界引張応力値がその継手の 降伏強さにほぼ等しいか，またはそれ以上の值を示す溶 接条件では，スリット形拘束割れ試験においてもルート 割れが発生しない。

ここで注意する必要のあるととは，HT 80 のように 強さのレベルの高い高張力鋼溶接部の TRC 試験や, $\mathrm{RRC}$ 試験において求められる限界応力値や限界拘束距 離が，溶接部の比較的低温度（約 $300^{\circ} \mathrm{C}$ 以下）の冷却 過程に大きく影響され，乙の温度域の冷却がはやくなる 
と限界応力值の低下が認められることである. これは後 に述べるように, 主として溶接部からの拡散性水素の逃 散に関係するものと考えられる。

ルート割れ発生の限界応力值や, 限界拘束距離が溶接 部の水素量にも影響されるととは前述のとおりである が，いま溶着金属の化学組成および機械的性質はほとん ぞ同じで, その水素量 (JIS 法) だけが異なる低水素系 溶接棒を用いて TRC 試験を行ない, その結果をまと めると Fig. 9 および10のようになる. HT 80 溶接部

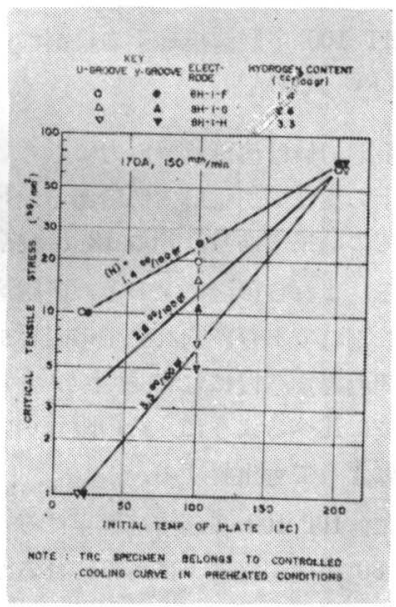

Fig. 9 HT 80 の TRC 試験による限界応力值と 板の初温および水素量との関係

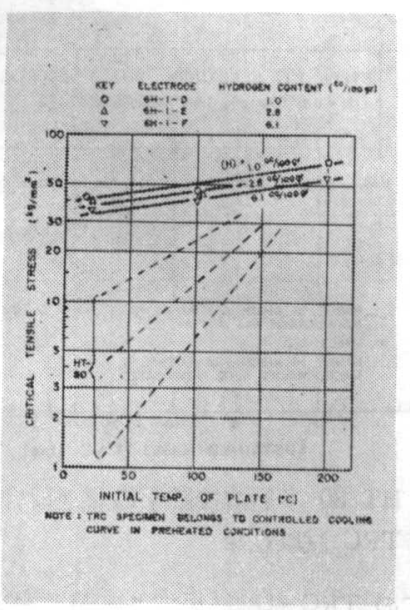

Fig. $10 \mathrm{HT} 60$ 用棒のU開先 TRC 試験による限 界応力值と板の初温および水素量との関係

については, Fig. 9 に示したように, 水素量が減少す るにしたがって限界応力值が急激に上昇するが, 予熱温 度の上昇にとあなう限界応力值の增加割合も水素量に依 存している.しかし Fig. 10 に示した HT 60 溶接部の 場合には, 水素量が $6.1 \mathrm{cc} / 100 \mathrm{gr}$ 以下の範囲ではいず
れも限界応力値が高く, 水素量の減少や予熱温度の上昇 にともなう限界応力值の上昇も， HT 80 溶接部の場合 にくらべてきわめて少ない，また，乙れらの結果から， ルート割れ防止のための予熱の勃果は HT 60 よりあ HT 80 に顕著に現われることす理解される.

\section{3 多層溶接時のマクロ割れ}

高張力鋼多層接溶継手に対して TRC 試験を適用する 之, 負荷方向に応じて, 横割れおよび縦割れの, いわゆ るマクロ割れが発生する2324)。(いま, HT 100 多層溶接 金属に溶接終了後, 溶接線方向または溶接線直角方向に ある限界荷重以上の長時間定荷重引張負荷を与えると,

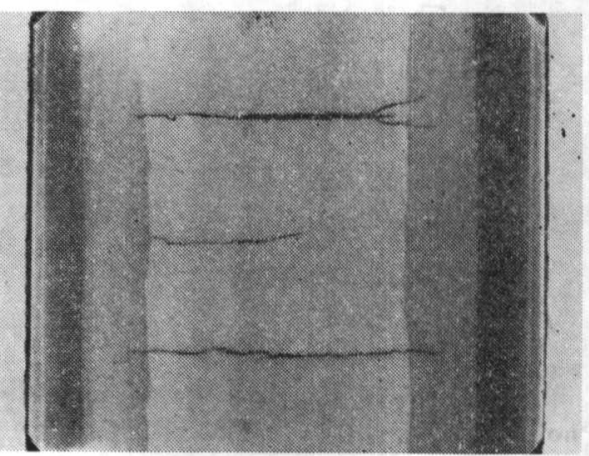

Photo. 2 多層溶接継手の TRC 試験において溶接 金属に生じた横割れの例

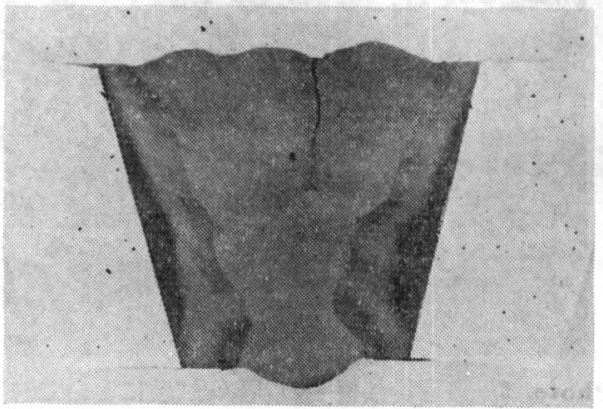

Photo. 3 多層溶接継手の TRC 試験において溶接 金属中に生じた縦割れの例

ある潜伏期間を経た後，それぞれ横割れ (Photo. 2) または縦割れ (Photo. 3 および 4 ) が発生する. これ らの割れを顕微鏡観察した結果では, Photo. 5 および 6 に示したように, 割れの近傍や，割れを生じた溶接金 属の他の部分にミクロ割れが存在するととから, 横割れ および縦割れは, ミクロ割れが成長して互いに連結し, ある程度の大きさのマクロ割れになった後に割れの先端 の切欠き効果によりさらに成長したものと考えられる.

ルート割れの場合とどうょうに, 引張応力值と負荷時 間を両軸にとって, HT 100 多層溶接継手の TRC 試験 結果を図示すると，Fig. 11 および12のようになる，乙 


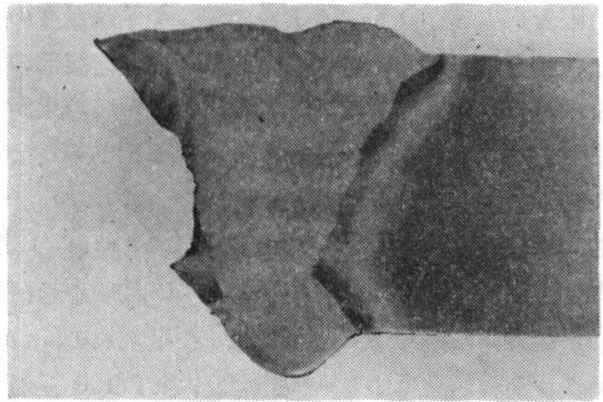

Photo. 4 多層溶接継手の TRC 試験において溶接 継手のボンドに沿った縦割れの例

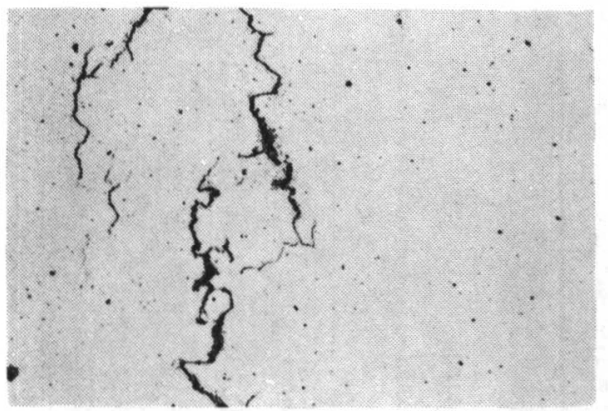

Photo. 5 多層溶接継手の TRC 試験において溶接 金属の横割れ近傍にあるミクロ割れの例

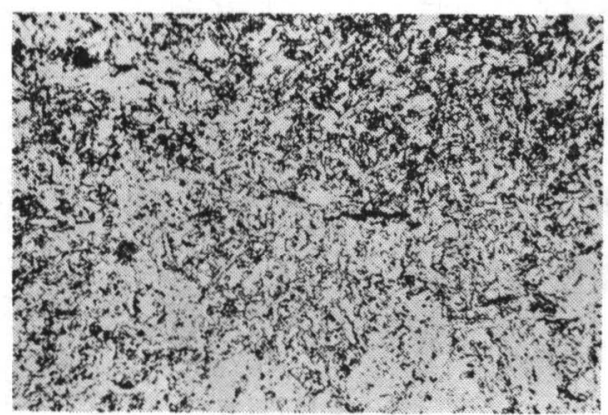

Photo. 6 多層溶接継手の TRC 試験において溶接 金属の縦割れ近傍にあるミクロ割れの例

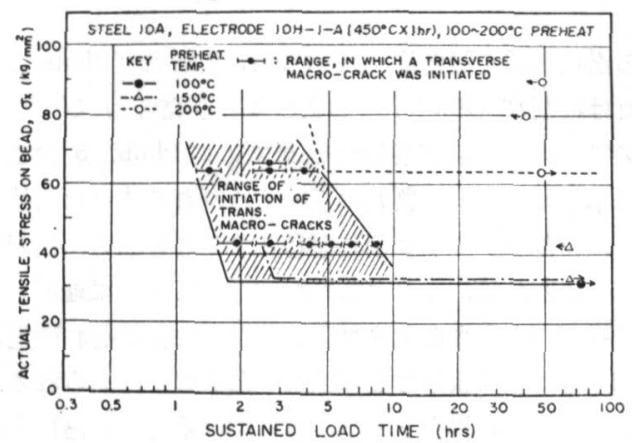

Fig. 11 HT 100 多層溶接継手の横割れについての TRC 試験結果

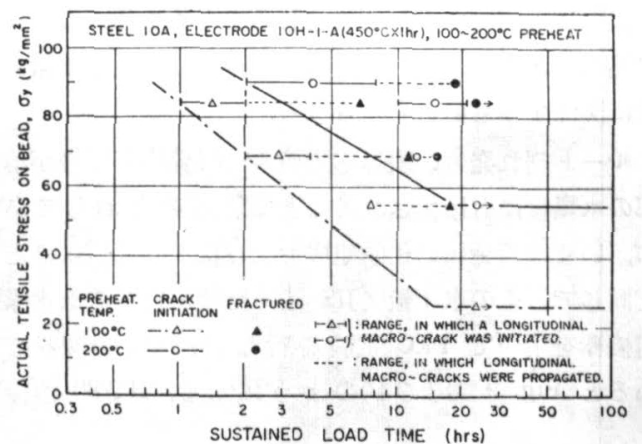

Fig. 12 HT 100 多層溶接継手の縦割れについての TRC 試験結果

の場合, 引張応力值は溶接残留応力值屯考虑して実測し た溶接金属上の実在の引張応力值である. Fig. 11 は横 割れについての結果であり, Fig. 12 は緃割れについて の結果である.これらの図によると, 多層溶接時のマク 口割れむ遅れ割れであり, 割れ発生の限界引張応力值は 溶接部の冷却過程が緩慢になると上昇するととがわか る、また, 後に述べるように, この限界引張応力值は水 素量の減少によっても上昇する.

このように, HT 100 多層溶接継手にみられたマクロ 割れは HT 80 多層溶接継手にあみられるが24), その限 界引張応力值は HT 100 の場合よりもむしろ高くなっ ており, 高張力鋼の強さが減ずると水素劣化の程度が軽 減されることを示している. Fig. 13 が HT 80 の横割

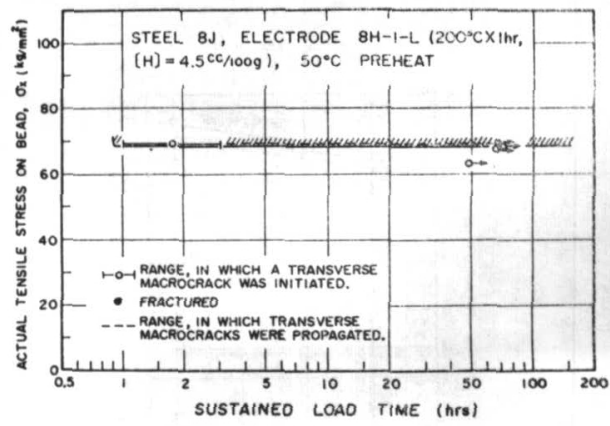

Fig. 13 HT 80 多層溶接継手の横割れについての TRC 試験結果

れについての TRC 試験結果であるが, 水素量が比較的 多い $(4.5 \mathrm{cc} / 100 \mathrm{gr})$ にかかわらず, $50^{\circ} \mathrm{C}$ 予熱で約 68 $\mathrm{kg} / \mathrm{mm}^{2}$ という継手の降伏点に近い限界応力值を示して いる. とれと同じ HT 80 とついて, 縦割れの限界応力 值を求めてみると, Fig. 14 および15に示したように, 水素量が比較的多く, $(4.5 \mathrm{cc} / 100 \mathrm{gr}) 50^{\circ} \mathrm{C}$ 予熱の場合 には約 $42 \mathrm{~kg} / \mathrm{mm}^{2}$ の值であるが, 普通の水素量 $(1.9$ $\mathrm{cc} / 100 \mathrm{gr})$ で, $100^{\circ} \mathrm{C}$ の予熱を行なうと, 約 $65 \mathrm{~kg} /$ 


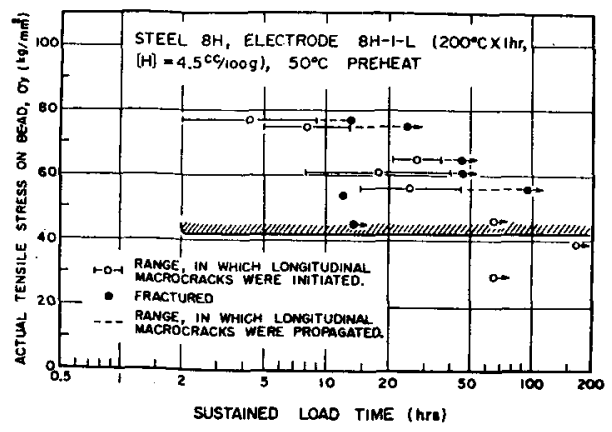

Fig. 14 HT 80 多屏溶接継手の綎割れについての TRC 試験結果（水素量の多い場合）

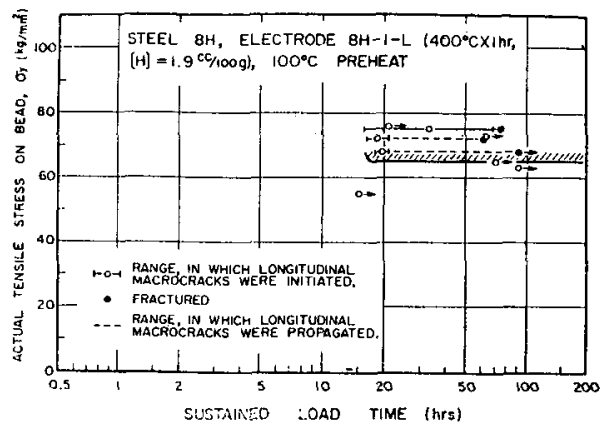

Fig. 15 HT 80 多層溶接継手の縦割れについての TRC 試験結果 (水素量が普通の場合)

$\mathrm{mm}^{2}$ の值に上昇する.

引張強さのレベルがさらに低い HT 60 多首溶接継手 では以上のようなマクロ割れはほとんど認められず，予 熱を行なわずに，継手の降伏点をてえる約 $58 \mathrm{~kg} / \mathrm{mm}^{2}$ の拘束応力を与えた場合でむ縦割れや横割れを生じな (24).

前項に述べた初層溶接時のルート割れと上述の多層溶 接時のマクロ割れについて，同じ鋼級で両者に対する感 受性を比較したのが Fig. 16〜18である，鋼種の相趓

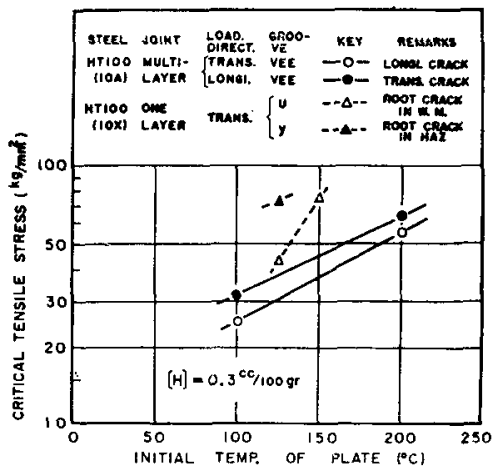

Fig. $16 \mathrm{HT} 100$ の多層和よび単畨溶接の TRC 試 験に上る限界応力值の比較

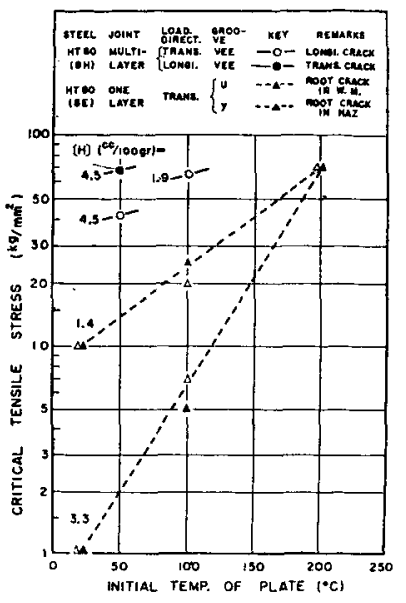

Fig. 17 HT 80 の多層および単層溶接の TRC 式 駼に招ける限界応力値の比皎

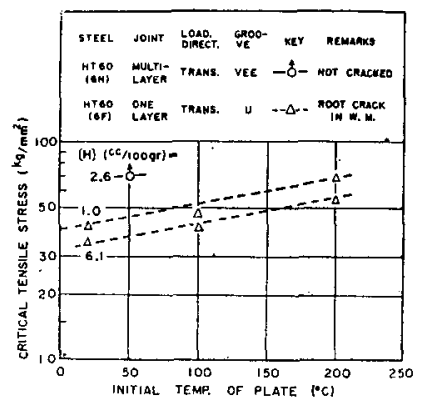

Fig. 18 HT 60 の多層および単層接棒の TRC 試 験における限界応力値の比較

はじやっかんあるにしても，Fig. 16 に示した HT 100 の埸合は別として，Fig. 17 に示した HT 80 の場合お よび Fig. 18 に示した HT 60 の埸合は，水素量や予 熱温度が同じであ，ルート割れ代対する限界応力值が多 首溶接時の横割れや縦割れについての限界応力値より低 いととから，実用的にはルート割れが防止できる施工 条件では，その他のマクロ割れが生ずる恐れはまず考え られないといえる、換言すれば，実際施工に当っては， 初層溶接時の予熱温度上りじやっか九低い予熱㬝間温度 で多層継手の溶接施工を行なえばじゅう分であるといえ る.ただし HT 100 の場合には，多層溶接の限界応力 值が初層のルート割れのそれよりも低く，予熱層閒温度 をルート割れ防止の場合よりじやっか九高くする必要が ある.

\section{4. 水素の影響}

\section{1 ビード下割れ}

ビード下割れにおよぼす水素の支配的な影響について は，すでに数外くの研究報告に述べられている。たとえ ば，Mallett 怙よび Rieppel の実験結果 ${ }^{25)}$ によると， 
合金鋼板上にビード溶接した場合，アーク雪囲気中の水 素容積（または）分圧が10\%以下になる，いわ的低水 素雾囲気ではビード下割れをほとえど生じていない，ま た Berry および Allan²6) が CTS 試験とビード䈯き試 験により $\mathrm{Ni}-\mathrm{Cr}-\mathrm{Mo}$ 鋼および低合金高張力鋼を用いて, 割れ（ビード下割れ抽よび溶接金属割れ），水素量およ び冷却速度の 3 者の定量的な関係を明らかにしている が，てれによると，銅種および冷却速度により相違する けれぞあおおよそ水素量が約 $4 \mathrm{cc} / 100 \mathrm{gr}$ 以下になり， 拘束の程度に応じて適当な溶接条件を選定すれば，割れ を生じなかった. Bradstreat の行なった， T-1 鋼の十 字形割れ試験結果 ${ }^{27)}$ です，被覆剂中の水分量が $0.16 \%$ 以 下（この場合の溶着金属水素量は約 $4 \mathrm{cc} / 100 \mathrm{gr}$ 以下之 推定される)では，ビード下割れを生じていない．

以上の結果からむわかるように，ビード割れ発生に限 界となる水素量は，鎡種，冷却過程および 3.1 項で述 べたように拘束度によって変わるので, ただちに決め難 いが，現在広く使用されているHT 80 程度では，約 $4 \mathrm{cc} / 100 \mathrm{gr}$ 以下に押えればまずビード下割れの心配は ないむのと考えられる。

\section{2 ルート割れ}

HT 60 および HT 80 の低水素系溶接棒の水素量が 3 段階に変ったものを用いてU開先拘束割れ試験を行な った結果，Fig. 19 および20に示したような結果をえ た ${ }^{15)}$. Fig. 19 に示した HT 60 の場合には,ルート割

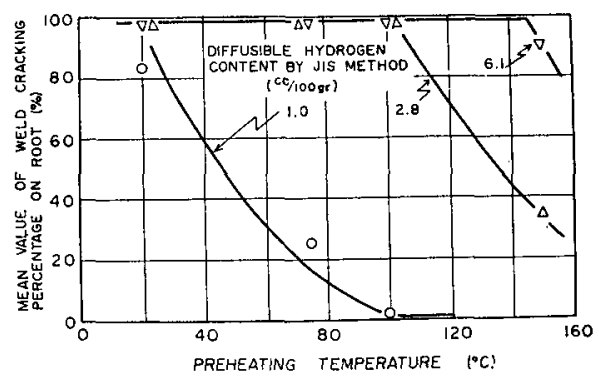

Fig. 19 HT 60 の U 開先ルート割れ発生に及ぼす 予熱温度と水素量の影響

れ率で判定できるルート制れの発生について，水素量が $1.0 \mathrm{cc} / 100 \mathrm{gr}$ から $2.8 \mathrm{cc} / 100 \mathrm{gr}$ に増加するだけで顕著 な影響がみられる，いっ ぱう，発生したルート割れの伝 播関しては，水素量が $2.8 \sim 6.1 \mathrm{cc} / 100 \mathrm{gr}$ の笨囲では その影響があまり変らず，HT 70 や HT 80 にくらべ てルート割れの伝播に対する感受性がきわめて小さいと とが求められている。

Fig. 20 に示した HT 80 の場合には，水素量の影響 が予熱温度 (冷却過程)に上って大きく左右されている ことが明らかであり，水素の影響を諭ずる場合にはまず

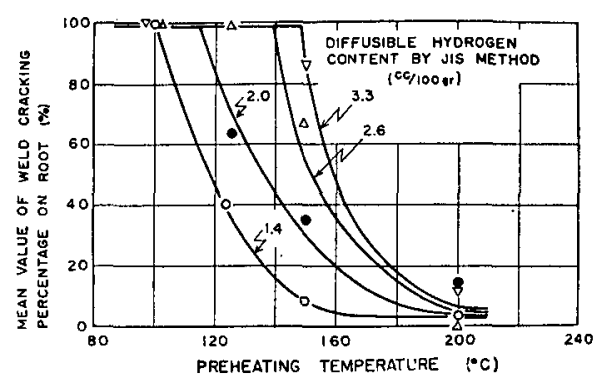

Fig. 20 HT 80 のU開先ルート割れ発生に及ぼす 予熱温度と水素量の影響

予熱温度（冷却過程）を決めてから論ずる必要がある，

(さらに厳密には 3.2 節で述べたように拘束応力の影 響も考虑して諭じることが必要である)ての図の結果か ら，予熱温度 $200^{\circ} \mathrm{C}$ の場合には，水素量が $3.3 \mathrm{cc} / 100$ gr までの範囲ではほとんどルート割れが発生せず，水 素の影響は認められない，WES規格などにおいて，板厚 $20 \mathrm{~mm}$ の HT 80 溶接施工時の標準的に予熱温度之考 えられている $150^{\circ} \mathrm{C}$ 予熱の場合には，水菜量が $2.0 \mathrm{cc}$ $/ 100 \mathrm{gr}$ 程度からルート割れ発生が顕著になっている。 さらに予熱温度が下がると割れが発生しはじめる限界水 素量が少なくなっていく、いっ弥う，発生した割れは， $1.4 \sim 3.3 \mathrm{cc} / 100 \mathrm{gr}$ の水素量汇関係なくきわめて伝播し やすいが，予熱温度が高くなるとルート割れ伝播に対す る感受性が低くなる傾向が認められている。

以上の議諭においては，いずれ屯水素量の影響を水素 試験で定量される水素量で取扱ってきたが，上述のよう に，そのような水素量の影響む冷却過程に左右される事 実と，割れ值接影響する水素量は，割れが発生する直 前に溶接部に残っている拡散性水素量で，ルート割れの 場合には，その発生危险温度域（約 $90^{\circ} \mathrm{C}$ 以下）まで冷 却したときの搪散性水素量を知る必要があるととの 2 点 から，筆者引は 2,3 の仮定をおいて， 1 層溶接金属の凝 固後の冷却過程におりる拡散性水素量の変化を推定する 方法を提案し，その罗当性を示した ${ }^{28)}$.

これによると，1層溶接金属の非状寸法を直径 $5 \mathrm{~mm}$ の無限円柱已仮定し，凝固㨁後加らの冷却曲線を細分し て，各温度区間の水素の平均拡散係数を用いて，溶接金 属中の水菜量の冷却途上における变化を近似的に計算し ている. その結果，上述のU開先拘束割机武片などのス リット形拘束割れ試片が，ルート割れ発生の危险温度域 の上限にほぼ等しい $100^{\circ} \mathrm{C}$ まで冷却した時に，凝固時 の水素量に応じて, Table 1 亿示した拡散性水美が残存 するあのと推定される，乙れによると，予熱定作用する ことにより格段に少ない水素量になり，上くに $200^{\circ} \mathrm{C}$ 
Table 1 種々の冷却過程で $100^{\circ} \mathrm{C}$ まで泠却されたスリット形割れ試験片の水 素量の推定值

\begin{tabular}{|c|c|c|c|c|}
\hline \multicolumn{2}{|c|}{$\begin{array}{c}\text { Diffusible Hydrogen in JIS } \\
\text { Hydrogen Test Specimen (cc/100 gr) }\end{array}$} & \multicolumn{3}{|c|}{$\begin{array}{l}\text { Diffusible Hydrogen in Crack ing } \\
\text { Specimen, Cooled to } 100^{\circ} \mathrm{C} \text { (Calcu), (cc/100 gr) }\end{array}$} \\
\hline $\begin{array}{l}\text { Extracted at } 45^{\circ} \mathrm{C} \\
\text { (Measured }\end{array}$ & $\begin{array}{l}\text { Just After Solidi- } \\
\text { fication (Calculated) }\end{array}$ & $\begin{array}{l}\text { Preheat Temp. } \\
\text { of Speci. is } 20^{\circ} \mathrm{C} \mid\end{array}$ & $\begin{array}{l}\text { Preheat Temp. of } \\
\text { Speci. is } 100^{\circ} \mathrm{C}\end{array}$ & $\begin{array}{l}\text { Preheat Temp. of } \\
\text { Speci. is } 200^{\circ} \mathrm{C}\end{array}$ \\
\hline 1.0 & 2.0 & 0.86 & 0.10 & 0.00 \\
\hline 1.5 & 3.0 & 1.29 & 0.15 & 0.00 \\
\hline 2.0 & 4.0 & 1.72 & 0.20 & 0.00 \\
\hline 2.5 & 5.0 & 2.15 & 0.25 & 0.00 \\
\hline 3.0 & 6.0 & 2.58 & 0.30 & 0.00 \\
\hline 3.5 & 7.0 & 3.01 & 0.35 & 0.00 \\
\hline 4.0 & 8.0 & 3.44 & 0.40 & 0.00 \\
\hline 5.0 & 10.0 & 4.30 & 0.50 & 0.00 \\
\hline 6.0 & 12.0 & 5.16 & 0.60 & 0.00 \\
\hline
\end{tabular}

Note; Welding condition of cracking specimen $(20 \mathrm{~mm})$ is $170 \mathrm{~A}, 24 \mathrm{~V}, 150 \mathrm{~mm} / \mathrm{mm}$.

予熱の場合にはほとんど拡散性水素が残存せず, 水素に よる遅れ割れ，すなわちルート割れを生ずる恐れはない あのと判断され，それが前揭の Fig. 20 にあ示されて いる.

以上述ベたルート割れにおよぼす水素量の影響は， ス リット型拘束割れ試験という．きわめて拘束のきびしい 場合についての結果である、3.2 節で述べたように, 割 れに対する限界水素量はまた作用する拘束力の值によっ ても変わるので, 最終的には水素試験で確められる水素 量（実際には割れを発生する瞬間の水素量が問題である ）のほかに，冷却過程扔よび拘束力も考慮して検討すべ き問題である.

\section{3 多層溶接時のマクロ割れ}

わが国ではじめて T-1 鋼を用いて球形タンクが製作 された時, 多層溶接金属にミクロ割れやそれが成長した マクロ割れが発生した。 それらの割れを防止するため 飞, 溶接棒被覆剂中の水分が $0.10 \%$ 以下（乙の場合の水 素試験における水素量はほぼ $2 \mathrm{cc} / 100 \mathrm{gr}$ 以下之推定さ れる）になるようにじゆう分な再乾燥を実施し，板厚 $25 \mathrm{~mm}$ の場合に $120^{\circ} \mathrm{C}$ の予熱を併用している ${ }^{5) 6}$.

わが国でも最近 1 部実用化されている HT 100につい て, 多層溶接継手の TRC 試験を行なったととは, すで に 3.3 節で述べたが, その試験で溶接棒の再乾燥条件 を変えて水素量を変化させ，横割れにおよぼす影響を調 べている. その結果を Fig. 21 亿示した. これによる と, $200^{\circ} \mathrm{C}$ 予熱を行なって, $65 \mathrm{~kg} / \mathrm{mm}^{2}$ の拘束応力が 作用しているときには, 水素量を $0.3 \mathrm{cc} / 100 \mathrm{gr}$ に押え れば横割れが発生しないが，降伏点より少し高い $90 \mathrm{~kg}$ $/ \mathrm{mm}^{2}$ の拘束応力の下ではその水素量であ横割れを生じ ている.

以上のようなマクロ割れは, HT 60 では認められず, HT 80 , HT 100 とその強さが増すにしたがって割れ発 生の限界水素量の值が低くなっていく.さらに, ルート 割れの場合とどうように，限界水素量の值は冷却過程と

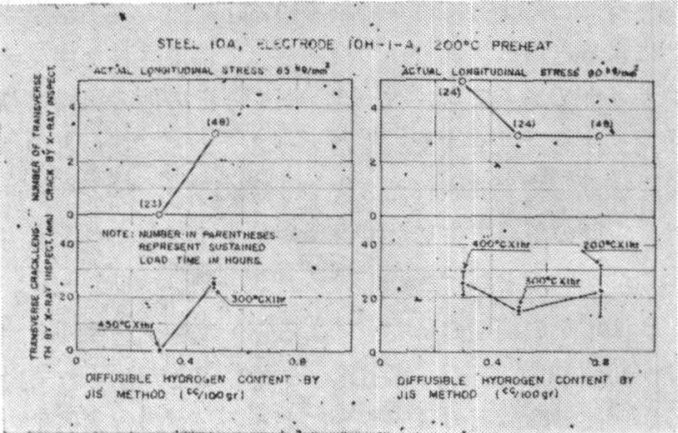

Fig. 21 HT 100 多層溶接継手の TRC 試験におけ る横割れにおよぼす水素量の影響

拘束力によってあ変わるので問題は複雑である. ただ, 3.3 節で述べたように, HT 60 および HT 80 の多層 溶接継手のマク口割れは, ルート割れが防止できる施工 条件では発生しない点と, 最近の国産 HT 80 はきわめ て割れ感受性が良好で, さきの Fig. 17 の結果から推 定されるように，予熱をほとんど併用せず，水素量む $4.5 \mathrm{cc} / 100 \mathrm{gr}$ 程度の比較的高い值でも, 実際の多層継 手にはマクロ割れを生ずる恐れがないと考えられる点か ら, 現在市販されている優秀な国産 HT 80 溶接材料を 用いて, メ一カ一側の推奖する溶接棒の使用前再乾燥処 理を忠実に実行すれば，まずこの種の割れの生ずる恐れ はないあのと考えられる.

\section{5. 組織の影響}

溶接部のかたさは, 古くから割れ感受性を示す目安之 されてきたが, 強さのレベルが等しい高張力鋼でも, ル 一ト割れが発生しはじめる限界かたさの值と割れ感受性 の間にはなんらの順位的な関係は認められない，ただ高 張力鋼の強さのレベルが高くなるにしたがって, ルート 割れが発生しはじめる硬さの範囲は上昇している。乙れ はルート割れ防止に対して限界となる熱影響部組織の面 積割合が，HT 60 ではマルテンサイト組織が $60 \%$ 以下 
(フェライトおよび中間段階組織が 40\%以上)， HT 70 では75\%以下（中間段階組織が $25 \%$ 以上，HT 80 では 90\%以下 (中間段階組織が10\%以上) 乙変化することと 対応している，てのように，いずれす低炭素の高張力鋼 が，その強さのレベルにより割れに対して限界となる組 織の面積割合が異なることは，主として溶接用 CCT 試 験における㚆態開始曲線の移動にあとずくあのと考えら れる。

溶接部の各種組織自体の水素劣化儿対する感受性を求 め，割れにおよぼす組織の影筫を基礎的に調查，研究す る試みが行なわれている。乙れは，主として，水素添加 した，各種熱サイクル再現切欠付試片の幄れ破境特性を 調べることによって行なわれている，著者の実験結果29)

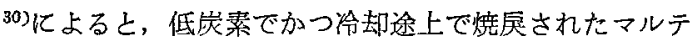
ンサイトであっても，ベーナイトや，その他の組織より 水䒺劣化を受けやすく，またオ一ステナイト域加らの急 冷を繰返して生成された 2 次や３次のマルテンサイト は， 1 回の急冷で生じた 1 次マルテンサイトより水素劣 化しやすいととが示されている.

Baker らの初期の研究31によると，マルテンサイト組 織がやはりむっとあ水素劣化しやすいととが示されてい るが，彼等の最近の研究 ${ }^{32>33}$ による上，鈵の水素劣化の 感受性怯針状組織のタイプに依存し，低炭素マルテンサ イト組織は低炭素のベーナイトとマルテンサイトの混在 組織より水素による劣化は軽微であると結諭している.

ての点については，さらに今後，検討を続ける必要が ある.

\section{6 . 低温割れの機構からみたその防止対策}

ビード下割れの発生機構については, 溶接部の泠却過 程で，熱影響部がオーステナイト組織である時に固定し ている水素が，マルテンサイト変態時に過飽和となって 各種結晶欠陷に析出した分子状水素の内生上，次に述べ る変態応力または収縮応力によってビード下割れを生ず ると説明されている.

ボンドに浴った熱影響部がマルテンサイト変態で膨張 すると，ボンド方句には圧縮応力が作用し，それに応じ て熱影響部に存在する結昆欠陷のところではボンドに直 角方向に引張応力が作用することが考えられ，その引張 応力によってボンドに平行にビード下割れを生ずる．ま た，溶接ビード方向または直角方向の収樎によって生ず る引張牫留応力によって，ビードに直角方向または平行 に熱影響部にビード下割れを生ずることあある、ビード に直有方向の収縮応力は拘束継手の場合に問題である。

小林の実験結果けによると，ビード下割れはマルテン サイト変態完了後, 加なりの時間経過してから発生して
いる. また著者の再現熱影響部試片の陰極䨪解水菜添加 実験に括いて，マルテンサイト組織の場合，試片表面近 くに表面に平行なミクロ割れが発生することがしばしば 経験された，乙れは著者の考えによると，試片表面から 水素が固溶しはじめるとまず試片表面が膨張しはじめ( 鎦に水素添加すると膨張变化があるととは実証されてい る), 内部は膨張をせず表面近くの膨張を拘束して，そ こに压縮応力を発生させ, 変態応力の場合とどうように 表面に平行な割れを発生させるすの上考えられる，てれ らの $2 つ の$ 結果から，ビード下割れの発生機椿しして， かならずしも熱影響部がオ一ステナイト時に水素を固溶 していて, マルテンサイト变態時に過飽和の水素を放出 するという機構でなくて屯，マルテンサイト組織になっ た熱響影部へ，溶接金属から水素が抎散していってビー ド下割れを生ずると考えることす可能である，実際の割 れはこの両者の舅合を含むのであろう。

以上のような機構で生ずるビード下割れを防ぐために は，周知のように低水素系溶接棒を用いるなどの方法で 溶接金属中の水素量を低くするととや，予熱を併用して マルテンサイト組織の出現を軽減し, かつ冷却過程中に 溶接部からの水素の放出をはかることが有効である，と くにビード下割れの発生が遲れ割れの特長を明暸に示す 場合には，後に述べる溶接直後の夙部後熱法や，低温後 熱法もその防止に有効であると考えられる.

ルート割れの機構は次のように考えられる．溶接終了 後, 時間の経過とと屯に溶接線方向之溶接線直角方向の 収縮によもなう引張応力が溶接部にかかってくるが，溶 接部の組織はマルテンサイトが優先する硬化組織で, 切 欠きを形成しているルート部では，応力集中にもとずく 局部的な塑性変形の進行之，多軸応力度にもとずく破壊 までの変形能の低下を生じるものと考えられる。溶接部 にはさらに溶接アーク発生中に高温度で吸収された抬散 性水素が，溶接部の急冷により過飽和状態となって固溶 している. 溶接終了後, 時間の経過とともに過飽和の拡 散性水素は昖散により大気中乩よび母材に向って逃散し ていく．その時にルート部はすでに局部的に塑性変形を 生じ，かつ多軸忍力状態になっているため，局部的に水

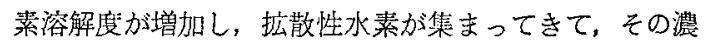
度が高くなる、ルート部の水素濃度がある值に達する 上, 硬化縕縕が水素出化を生じ, 多蚰応力状態による变 形能の低下と相まって破境，すなわちルート割れを発生 する、そしてルートから発生した制れの先端が新たな切 欠きとなりふふたたび上述のような機構を繰返してルー 卜割れが段階的に伝播していく向の之考えられる.

このようなルート割れ発生機構加ら䓔えて, 溶接部の 組織を水素少化化対して安全な题性に富む組織にす̣る 
か、または溶接後，ルート割れが発生するまでの潜伏時 間のうちに防止処理を施すかの 2 つのルート割れ防止対 策が考えられる，前者化対する現場的な力法は，均一予 熱老行なう以外に溶接直前敒開先面近傍在局部予熱し溶 接部の冷却をじゅう分縓慢にする方法がある．後者住対 する方法として, 溶接部の組織が水素劣化に対して危險 な硬化組織になっても，割れが発生するまでの潜伏期間 において，その組織を焼もどすとともに，溶接部の水素 あ放出してルート割れの防止をはかる局部捘熱法があ る. 代表的な HT 80 である T-1 鋁の場合にてれらの 方法を適用して，その効果が確認されたが，局部後熱を 行なうに当っては, 溶接後, 溶接部のボンドにおける温 度が $200^{\circ} \mathrm{C}$ 以下に冷却しない時期に，最高後熱温度 $500^{\circ} \mathrm{C}$ 以上の, 溶接ビード表面からの局部後熱を行なう 必要のあることがわかった。

多層溶接継手のマク口割れは，溶接部敒発生したミク 口割れが連なってある程度の大きさのマクロ割れにな り，その先端が切欠きとなって，ルート割れの場合と類 似の機構で成長するるの之考えられる。この制れの現場 的な防止対策として，じゅう分な均一予熱を併用する以 外に，予熱温度を低くして，かつルート割れ防止の場合 とどうような局部後熱法を各層に対して適用する方法が 有効であることが確められている，さらにこの割れの防 止方法として, 溶接完了後, $100 \sim 200^{\circ} \mathrm{C}$ の温度で $5 \sim 1$ $\mathrm{hr}$ の水素除去加熱を行なう，いわゆる低温後熱法も有 効である.

\section{参考文献}

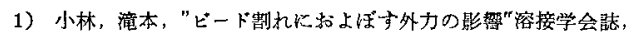
29巻, 9㤐, 668-669 (1960)

2) S. Weiss, J.N. Ramsey and H. Udin, "Evaluation of Weld Cracking Tests on Armor Steel" Wdg. JnI. Res. Suppl., Vol. 35, No. 7, 348 S (1956)

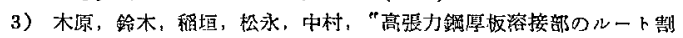
九㒃験結果”，溶接学会踗，33巻，3号，(1964）

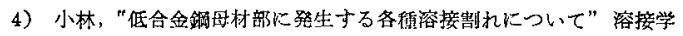
会 蛁和 30 年春季新演会発表

5) P. C. Arnold; "Problems associated with the welding of T-1 materials" wdg. Jnl. Res. suppl. Vol. 36, No. $8,373 \mathrm{~s}-381 \mathrm{~s}(1957)$

6）桂, 山猗, 前田，小倉，“T-1 銅の容揬性（第 2 報)”石川鳥技報 16巻, 55是, 37-44 (1959)

7) A. E. Flanigan "An Investigation of the Influence of Hydrogen on the Ductility of Arc Welds in Mild Steel" Wdg. Jnl. Res. Suppl., Vol. 28, No. 5, 216s-225s (1949)

8) A. E. Flaneigan and M. Kaufman, "Microcracks and the Low-Temperature Cooling Rate Embrittlement of WeIds" Wdg. JnI, Vol. 30, No. 12, 613 s-622 s (1951)

9) A. E. Flanigan and Z. P. Saperstein, "Isothermal studies on the weld-metal microcracking of arc welds in mild steel" wdg. Jnl., Vol. 35, No. 11, $541 \mathrm{~s}-556 \mathrm{~s}$ (1956)
10) E. C. Rollason and R. R. Roberts, "Effect of Cooling Rate and Composition on the Embrittlement of weld Metal" Jn1, Bron \& Steel Inst., Vol. 166, No. 10, 105112, (1950)

11) T. E. M. Jones, "Cracking of Low-Alloy Steel weld Metal", Brit. Wdg. Jn1., Vol. 6, No.7, 315-323 (1959)

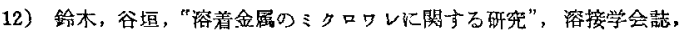
33巻, 10号, 508-515 (1964)

13) G. M. Evans and N. Christensen. "Micro-fissuring of Multi-Run Mild Steel weld Metal", Brit. Wdg. Jnl., Vol. 10, No. 10, 508-515 (1963)

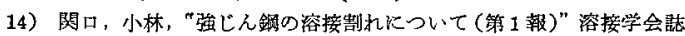
17 巻, 9 号, $313-320$

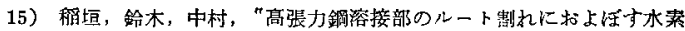

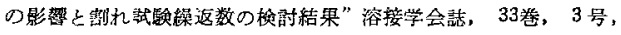
191-202 (1964)

16) A.E. Flanigan, J.L. Kaae, "The Temperature-Dependence of Underbead Cracking in an Arc-Welded Low. Alloy Steel" Wdg. Jn1. Res. Suppl., Vol. 43, No. 2, $80 \mathrm{~s}-85 \mathrm{~s}$ (1964)

17) 中村, “高張力鍓容接部のルート割机の研究”大阪大学学位諭交 (1964)

18）渡边，位滕，“溶接継手の拘束度执よび拘束応力に關する研究 （第 1 報)" 造船㙝会論文集，110号，349-358（1961）

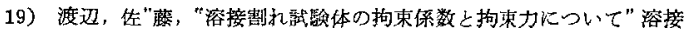
学会誌, 33卷, 7号, 513-523 (1964)

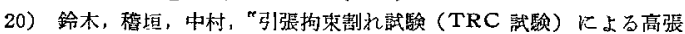

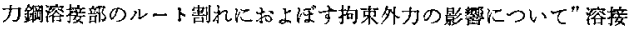

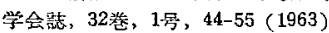

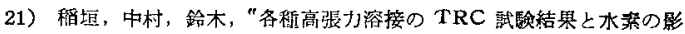

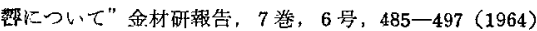

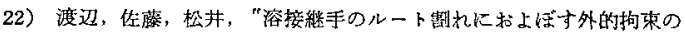
影整”溶接学会誌 33登, 6 号，446-457(1964)

23）㸺垣，中村，中原，三谷，“大型 (1000屯) TRC 試験機に上る多層 溶接秤奉の割れ炕関寸る研究”，UH 委，第 1 分科会提出資料 (1964)

24）啝垣，中村，明石，复目，“広巾溶接辚手の掘礼破堎特性の研究” HT 委員会提出筫料 (1966)

25) M.W. Mallett, R.J. Rieppl, "Arc Atomospheres and Underbead Cracking" Wdg. Jnl. Res. Suppl., Vol. 25, No. 11,748 s-759 s (1946)

26) J.T. Berry and R.C. Allan "A Study of Cracking in Low-Alloy Steel Welded Joints" Wdg. Jn1. Res. Suppl., Vol. 39, No. 3, 105 s-116s (1960)

27) B.J. Bradstreat. "Application of the Cruciform Test to a Study of Cracking in T-1 Steel Weldments" Wdg. Jn1. Res. Suppl., Vol. 41, No. 2, $62 \mathrm{~s}-69 \mathrm{~s}$ (1962)

28) M. Inagaki, H. Nakamura and H. Suzuki; "Effect of Microstructure on Root Cracking in High Strength Steel Welds and Behavior of Hydrogen" Trans. NRIM, Vol. 6, No. 6, 402-419 (1964)

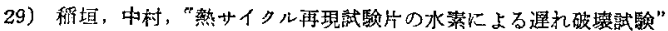
UH 委員会第 1 分科会提出資料 (1964)

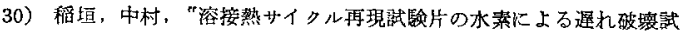
臨”，9 N 委員会提出資料（1965）

31) F. Watkinson, R.G. Baker and A.F. Tremlett, "Hydrogen Embrittlement in Relation to the Heat-affected zone Microstructure of Steels" Brit. Wdg. Jnl. Vol. 10, No. 2, 54-62 (1963)

32) T. Boniszewski, F. Watkinson, R.G. Baker and H.F. Tremlett, "Hydrogen Embrittlement and Heat.Affected zone Cracking in Low-Carbon Alloy Steels with Acicular Microstructures", Brit. Wdg. Jn1., Vol. 12, No. 1, 14-36, (1965)

33) T. Boniszewski and R.G. Baker, "Hydrogen Embrittlement in Low Carbon Nickel and Manganese Steels" Brit. Wdg. Jnl., Vol. 12, No. 7, 349-362 (1965) 